\title{
Wild Chamomile [Cladanthus mixtus (L.) Chevall.] Collected from Central-Northern Morocco: Phytochemical Profiling, Antioxidant, and Antimicrobial Activities
}

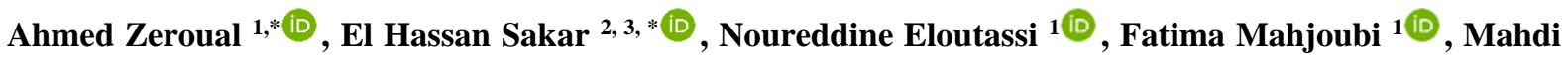

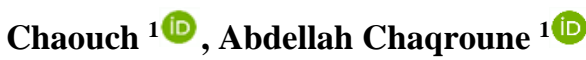

1 Laboratory of Materials Engineering and Environment, Department of Chemistry, Faculty of Sciences Dhar Mahraz Fez, Sidi Mohamed Ben Abdellah University, B.P. 1796 Fez-Atlas, 30003 Fez, Morocco; zeroualahmedbio@ gmail.com (A.Z.); eloutassi.noureddine@usmba.ac.ma (N.E.); mahjoubi.fatima@usmba.ac.ma (F.M.); chaouch.mahdi@usmba.ac.ma (M.C.); chaqroune.abdellah@usmba.ac.ma (A.C.)

2 Department of Biology, Faculty of Sciences of Tetuan, Abdelmalek Essaâdi University, B.P. 2121 Mhannech II. 93002, Tetuan, Morocco; hassan.sce@ gmail.com (E.H.S)

3 Laboratory of Natural Resources and Environment, Polydisciplinary Faculty of Taza, Sidi Mohamed Ben Abdellah University, B.P 1223, Taza-Gare, Taza, Morocco;

* Correspondence: zeroualahmedbio@gmail.com (A.Z.); hassan.sce@gmail.com (E.H.S.);

Scopus Author ID 57194743663

Received: 15.11.2020; Revised: 5.12.2020; Accepted: 7.12.2020; Published: 11.12.2020

\begin{abstract}
We investigated phytochemicals and biological activities in Cladanthus mixtus essential oil (CMEO) and various extracts. To this end, flowers CMEO microwave-extracted was subjected to chemical analysis using GC-MS. Antimicrobial activities of CMEO and various extracts obtained by maceration and Soxhlet were tested against four microbial strains using agar well diffusion assay and microtitration method. Antioxidant activities were determined, for extracts, using DPPH. CMEO chemical composition revealed 44 compounds. Santolina alcohol (40.7), germacrene D (8.9), and $\alpha$ pinene $(5.7 \%)$ were the main constituents. The best records of yield, total phenolics, and flavonoids were obtained with Soxhlet and methanol for extracts. Important antimicrobial activities were recorded in CMEO and extracts. For CMEO, MICs ranged from 10.17 (Bacillus subtilis ATCC 3366) to 13.83 $\mu \mathrm{g} / \mathrm{mL}$ (Escherichia coli ATCC 25922). Among extracts, Met-OH was the most efficient with MICs ranged from 11.17 (Candida albicans ATCC 10231) to $15.83 \mu \mathrm{g} / \mathrm{mL}$ (E. coli). Met-OH extract presented the highest antiradical activity $\left(\mathrm{IC}_{50}=55.50 \mu \mathrm{g} / \mathrm{mL}\right)$, while the $\mathrm{n}$-hexane displayed the lowest one $\left(\mathrm{IC}_{50}=259 \mu \mathrm{g} / \mathrm{mL}\right)$. Based on these outcomes, CMEO and various extracts from Cladanthus mixtus flowers could be suggested for their use as potential natural preservatives to enhance foods shelf-life, herbal formulations, and also as antiseptics and disinfectants.
\end{abstract}

Keywords: Cladanthus mixtus; phytochemicals; green extraction; santolina alcohol; biological activity.

(C) 2020 by the authors. This article is an open-access article distributed under the terms and conditions of the Creative Commons Attribution (CC BY) license (https://creativecommons.org/licenses/by/4.0/).

\section{Introduction}

It is widely evidenced that there is a global emergence of resistant microorganisms, which is increasingly restricting the potency of the currently available drugs [1], resulting in a failure in the management and treatment of infections [2]. Therefore, the prevalent antibiotic's effectiveness has been reported to decrease steadily, leading to a 'post-antibiotic' era, as 
reviewed in Reardon (2014) [3]. Moreover, according to several estimations, a persistent rise in antibiotic resistance would lead to about 10 million deaths yearly by 2050 , as evidenced in O'neill (2014) [4] and Mendelson (2015) [5]. Besides, this situation is getting worse, causing the misuse and overuse of antibiotics. In this context, there is a pressing need to explore novel strategies to fight drug-resistant microorganisms. Because microbes' multidrug resistance became a major concern since it represents a global threat to public health, the natural products screening to search for new antimicrobial agents has become imperative [6,7]. In fact, recently, plants and associated secondary metabolites have received much attention from the scientific community, emphasizing their therapeutic potentials [8,9]. In this regard, many plants used in traditional medicine to treat different illnesses have been demonstrated to be more effecient, not expensive compared to conventional drugs. They have less or even no side effects [10].

An essential part of the chemical species (especially secondary metabolites) produced by plants is to protect them against pathogens [1]. In this context, various plant extracts and related compounds have been reported to have important antimicrobial powers both in vitro and in vivo [11].

Besides, Morocco is deemed to be one of the most important floristic areas in Northern Africa. This enormous plant diversity is due to its geographical position, climate, diverse geology, topography, and ecoregion [12]. The Moroccan flora is estimated to encompass 978 endemic taxa, over half of the North African endemic plant species [13]. This endemic richness is ascribed to the presence of mixed and clear differentiated environments, as highlighted in Ranko et al. (2013) [12].

The Cladanthus genus (formerly known Chamaemelum then Ormenis), which belongs to the Asteraceae cosmopolitan family, comprises 130 species widespread in Mediterranean areas (including Morocco), South Africa, Southwest Asia, and Western Europe [14]. Among them, Moroccan chamomile is botanically known as [Cladanthus mixtus (L.) Chevall.] with several previous synonyms [= Ormenis mixta (L.) Dumort.; Chamaemelum mixtum (L.) All. Anthemis mixta L.]. It is a spontaneous annual plant (10-40 cm tall with fragrant white/ yellow flowers) that grows widely in northern Morocco and along the Atlantic coast on sandy soils $[15,16]$. It is mainly used for essential oil (EO) extraction. Morocco is the main supplier of EOs of this species in the international market. Cladanthus mixtus (C. mixtus) EOs are used both in perfume and pharmaceutical industries, according to Benjilali and Zrira (2005) [17]. Likewise, the infusion of leaves and flowers are also used in Moroccan folk medicine thanks to its numerous health-healing properties, including antiseptic, anti-inflammatory, antibacterial, antispasmodic, and sedative effects [18-21].

Despite its valuable EOs and pharmacological properties, C. mixtus has received little attention regarding its chemical composition. Under the different previous scientific names, some studies have addressed the phytochemistry and biological properties of $C$. mixtus extracts [22-24]. Elouaddari et al. (2019a) [21] reviewed C. mixtus EOs chemical composition and related biological activities. Following the authors' review, EOs yield ranges from 0.06 to $1.56 \%$ and varies greatly among geographical areas. Higher yields were reported to be in dry environments, while the wetter ones displayed relatively lesser yields. According to the same authors, phytochemicals found in C. mixtus EOs encompass 264 compounds with wide variations depending on factors such as environments, plant parts (leaves, flowers, or stems), extraction technology, etc conditions, among others. These compounds are distributed, in decreasing order, as follows: Oxygenated monoterpenes (30-45.3\%), monoterpene hydrocarbons (15-24.5\%), sesquiterpene hydrocarbons (14-33.9\%), oxygenated 
sesquiterpenes (4-11.7\%), and others (traces-4.5\%). This biochemical richness is behind numerous properties like antimicrobial activities, anticorrosive, and cytotoxic activity against human cervical cancer cell lines.

To the best of our knowledge, no detailed information about phytochemicals and associated biological activities in C. mixtus growing in central-northern Morocco hence the originality of this research work, which had as objectives, (i) to assess antioxidant and antimicrobial activities of aerial parts from $C$. mixtus, (ii) to investigate the EO phytochemical composition of this species, and (iii) to compare extracts obtained using various solvents in terms of yield, total phenolics, total flavonoids, and their antioxidant and antimicrobial activities.

\section{Materials and Methods}

\subsection{Chemicals, solvents, and reagents.}

All reagents and solvents used were of the highest purity. 2,2-diphenyl-1picrylhydrazyl (DPPH), ascorbic acid, methanol, n-hexane, ethanol, ethyl acetate, aluminum chloride $\left(\mathrm{AlCl}_{3}\right)$, sodium carbonate, sodium sulfate, Folin-Ciocalteu, dimethyl sulfoxide (DMSO), gallic acid (GA), quercetin (Q), and potassium acetate were used in this work. These chemical reagents were acquired from Stigma-Aldrich (St. Louis, MO). All other chemicals and solvents used were of analytical grade.

\subsection{Plant material and extracts preparation.}

Firstly, the plant species has been botanically authenticated by Prof. A. Ennabili from the Higher School of Technologies (SMBA University, Fez, Morocco). At full blooming, flowers (the aerial parts) of $C$. mixtus were collected in May 2018 from the Mezraoua region (15 km from Taounate province, $34^{\circ} 31^{\prime} 48^{\prime \prime} \mathrm{N}, 4^{\circ} 42^{\prime} 36^{\prime \prime} \mathrm{W}$ ). This region belongs to Centralnorthern Morocco, characterized by a Mediterranean climate humid in winter and semi-arid in summer. The sampled plants were dried in a dark room to avoid the photo-oxidation, then crushed using an electric grinder to a fine powder subjected to extraction via maceration. Briefly, $25 \mathrm{~g}$ of powder were used for extraction using various solvents separately (ethanol, ethyl acetate, methanol, and n-hexane). The extraction was achieved throughout $72 \mathrm{~h}$. The obtained extracts were then filtered through Whatman No. 1 filter paper. The residue was reextracted twice. The combined extracts of every sample were evaporated, at a temperature of $45^{\circ} \mathrm{C}$, using a rotary evaporator (Heidolph Collegiate, LV28798826, New Jersey, USA). The obtained samples were used to study their antioxidant and antimicrobial activities [25].

\subsection{EOs isolation.}

C. mixtus EOs were isolated using two different methods: Microwave and hydrodistillation, as described below. The yields of oils were calculated and expressed (in \%) per weight of the dried plant material. After that, only EOs obtained via microwave were subjected to phytochemical profiling using gas GC-MS. According to published literature $[26,27]$, the microwave method has several advantages over traditional alternatives such as shorter isolation time ( 15 min versus $3 \mathrm{~h}$ required for hydrodistillation), environmental impact (lower energy cost), a cleaner method (since no residue generation and no solvents used), 
enhances antimicrobial and antioxidant activity, and provides more valuable EOs (higher amount of oxygenated phytocompounds).

\subsubsection{Microwave-assisted extraction.}

Solvent-free microwave extraction has been performed following Lucchesi et al. (2004) [26] in a Milestone "DryDist" microwave laboratory oven. This is a multimode microwave reactor $2.45 \mathrm{GHz}$ with $10^{3} \mathrm{~W}$ as maximum power. An external infrared sensor controlled the temperature. $100 \mathrm{~g}$ of plant material were heated, at atmospheric pressure, using a fixed power density of $1 \mathrm{~W} \mathrm{~g} \mathrm{~g}^{-1}$ for 15 min without solvents or water. The direct interaction of microwaves with biological water (present in the fresh plant material) fosters the release of EOs contained inside the plant tissues. The mixture of hot "crude juice" and in situ water move, thanks to earth gravity downwards, on a spiral condenser where it condensed. In a receiving flask, oily condensate was collected continuously. At the end, EO was collected, dried via anhydrous sodium sulfate, and stored at $4{ }^{\circ} \mathrm{C}$ until used.

\subsubsection{Hydrodistillation.}

To isolate EO from $C$. mixtus, dried aerial parts (flowers) were subjected to hydrodistillation using a Clevenger-type apparatus. Three independent distillations involving $100 \mathrm{~g}$ of plant material were carried out by boiling, for three hours, in a 1-liter flask topped by a column of $60 \mathrm{~cm}$ length connected to a refrigerant as described in Jennan et al. (2018) [28]. Separation of the obtained EO from the water was done using decantation. EO was then dried over anhydrous sodium sulfate and kept in amber vials at $4{ }^{\circ} \mathrm{C}$ until use.

\subsection{Phytochemical profiling of EO using gas GC-MS.}

The EO analysis, achieved through microwave extraction, was carried out according to Talbaoui et al. (2016) [29]. It was carried out using a TRACE GC ULTRA equipped with nonpolar VB5 (95\% methyl polysiloxane, and 5\% phenyl), capillary column $(30 \mathrm{~m} \times 0.25 \mathrm{~mm}$ i.d. and $0.25 \mu \mathrm{m}$ as a film thickness), directly coupled to a mass spectrometer (Polaris Q) (EI 70 $\mathrm{eV}$ ). The temperatures of the injector and detector were set at 250 and $300{ }^{\circ} \mathrm{C}$, respectively. The oven temperature was programmed to increase at $4{ }^{\circ} \mathrm{C} / \mathrm{min}$ from 40 to $180{ }^{\circ} \mathrm{C}$ and at 20 ${ }^{\circ} \mathrm{C} / \mathrm{min}$ for $180-300{ }^{\circ} \mathrm{C}$. The gas carrier was helium with a flow rate of $1 \mathrm{~mL} / \mathrm{min}$; the sample $(1 \mu \mathrm{L})$ was injected according to a splitless mode.

\subsection{Total phenolics and flavonoids determination.}

\subsubsection{Determination of total phenolics content (TPC).}

TPC was determined using the Folin-Ciocalteu method [30] with slight modifications. Briefly, $100 \mu \mathrm{L}$ of extracts $(1 \mathrm{mg} / \mathrm{mL})$ were added to $500 \mu \mathrm{L}$ of $1: 10$ Folin-Ciocalteau reagent (prepared before use). After $4 \mathrm{~min}, 400 \mu \mathrm{L}$ of sodium carbonate $7.5 \%(\mathrm{~m} / \mathrm{v}: 75 \mathrm{mg} / \mathrm{mL})$ were added. The mixture was incubated for $90 \mathrm{~min}$ at room temperature; the optical density was then read at $765 \mathrm{~nm}$ using a Cary $50 \mathrm{UV}$-Visible Spectrometer (Varian, Mulgrave, Australia). A standard curve was prepared using gallic acid $(\mathrm{GA}, 5 \mathrm{mg} / \mathrm{mL})$ with various concentrations ranging from 0 to $150 \mu \mathrm{g} / \mathrm{mL}$. The results were expressed as GA equivalents (GAE) per $\mathrm{g}$ of sample (dry matter, DM). 
2.5.2. Determination of total flavonoid content (TFC).

TFC was determined using the aluminum trichloride colorimetric $\left(\mathrm{AlCl}_{3}\right)$ method [31] with slight modifications. Briefly, $250 \mu \mathrm{L}$ of extracts $(2 \mathrm{mg} / \mathrm{mL})$ were mixed with $50 \mu \mathrm{L}$ of $\mathrm{AlCl} 3(10 \%, \mathrm{~m} / \mathrm{v}), 750 \mu \mathrm{L}$ of absolute ethanol, $1.4 \mathrm{~mL}$ of deionized water, and $50 \mu \mathrm{L}$ of potassium acetate $(1 \mathrm{M})$. The mixture was incubated at room temperature for $30 \mathrm{~min}$; the absorbance was then measured at $415 \mathrm{~nm}$. Quercetin was used to carry out the standard curve. The results were expressed as a gram of quercetin equivalents $(\mathrm{QE})$ per $g$ of sample (dry matter, DM).

\subsection{Antioxidant activities assessment.}

The ability to trap the radical DPPH (2,2-diphenyl-1- picrylhydrazyl) was determined by the standard method described in Brand-Williams et al. (2015) [32] with some modifications. Briefly, at least $0.2 \mathrm{~mL}$ from various concentrations $(30-480 \mu \mathrm{g} / \mathrm{mL})$ of $C$. mixtus extracts were added to $1.8 \mathrm{~mL}$ of the $\mathrm{DPPH}$ methanolic solution at $0.11 \mathrm{mM}$. After incubation in darkness at room temperature $\left(23 \pm 2{ }^{\circ} \mathrm{C}\right)$ for $30 \mathrm{~min}$, the absorbance was measured at $517 \mathrm{~nm}$ against a DPPH methanolic blank solution. The DPPH radical scavenging activity (also known as antioxidant activity, AA) have been calculated based on the following equation:

$$
\%(\mathrm{AA})=\left[\frac{\left(\mathrm{Abs}_{\mathrm{control}}-\mathrm{Abs}_{\mathrm{sample}}\right)}{\mathrm{Abs}_{\mathrm{control}}}\right] \times 100
$$

Where $\mathrm{Abs}_{\text {control }}$ is the absorbance of the control reaction (containing all reagents, except the test sample)

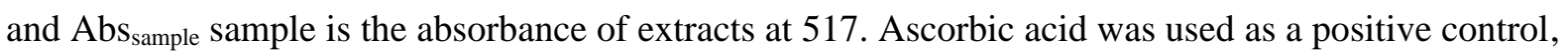
and the concentration of extracts that inhibit $50 \%\left(\mathrm{IC}_{50}\right)$ of DPPH was computed based on the percentage graph inhibition following the extract concentration using the exponential equation.

\subsection{Determination of antimicrobial activities.}

Microbial strains used here are of significant concern in problems health and food spoilage as previously described in our previous works [33,34]. EO and extracts obtained using various solvents were tested for antimicrobial activities against the following strains: Escherichia coli ATCC 25922 (E. coli), Staphylococcus aureus ATCC29213 (S. aureus), Bacillus subtilis ATCC 3366 (B. subtilis), and Candida albicans ATCC 10231 (C. albicans).

\subsubsection{Disc diffusion assay.}

The antimicrobial activities of the extracts were examined following the disk diffusion method [35]. Briefly, microbial strains were cultured overnight at $37{ }^{\circ} \mathrm{C}$ on Luria-Bertani broth. After that, an inoculum consisting of $0.5 \mathrm{McFarland}$ was prepared. A $100 \mu \mathrm{L}$ of bacterial inoculum was inoculated onto Petri dishes containing a sterile medium of Luria-Bertani agar. Sterile filter paper discs (diameter consisting of $5 \mathrm{~mm}$ ) were deposited on the medium and impregnated with $10 \mu \mathrm{L}$ of extract solution $(500 \mathrm{mg} / \mathrm{mL}$ of dimethyl sulfoxide [DMSO] at $2 \%$ ). The control was carried out with discs containing $10 \mu \mathrm{L}$ of DMSO at $2 \%$.

2.7.2. Minimum inhibitory concentration (MIC) of plant extracts and Eos.

To determine MICs, the agar dilution method was used as recommended by the Natural Committee for Clinical Laboratory Standards [36]. All tests were performed in nutrient broth 
for bacterial strains. Various concentrations $(7.5,10,12.5,15$, and $20 \mu \mathrm{g})$ from dry extracts and EO were added separately to $1 \mathrm{~mL}$ nutrient broth tubes containing $105 \mathrm{CFU} / \mathrm{mL}$ of live bacterium's cells. To spread the extracts and EOs throughout the broth, the tubes (contained 10 $\mathrm{mL}$ broth) were incubated in an incubator shaker. The highest dilution (the lowest concentration), displaying no visible bacterial growth, was considered MIC. After that, cells from the tubes showing no growth were cultured on nutrient agar plates to determine whether the inhibition was permanent or reversible.

\subsection{Statistical analyses.}

All determinations and measurements were achieved, at least in triplicates. The combined analyses of variance (ANOVA) were computed to assess magnitude effects of extraction techniques and solvents used on yield, TFC, and TFC. Quantitative differences were assessed by the general linear procedure followed by Duncan's test. Data statistical analyses were performed using the SPSS package version 23 (IBM, Armonk, NY, USA). Values were expressed as means \pm standard deviations (SD). Differences were considered significant at $5 \%$ as a probability level. Principal component analysis (PCA) was performed on mean values to discriminate among solvents and extraction techniques using STATGRAPHICS package version XVIII (Statpoint Technologies, Inc., Virginia, USA).

\section{Results and Discussion}

\subsection{Results.}

\subsubsection{Chemical composition of EO.}

The yield of EOs (of a yellowish color) obtained from C. mixtus flowers by both and microwave and hydrodistillation was expressed as the percentage of plant dry weight. EO yield obtained by microwave $(0.79 \pm 0.06 \%)$ was higher than that achieved using hydrodistillation $(0.53 \pm 0.09 \%)$. The obtained chromatogram (Fig. 1) for EO chemical composition was characterized by 44 chemical compounds (Table 1) accounting for $96.9 \%$ of the total chemical composition.

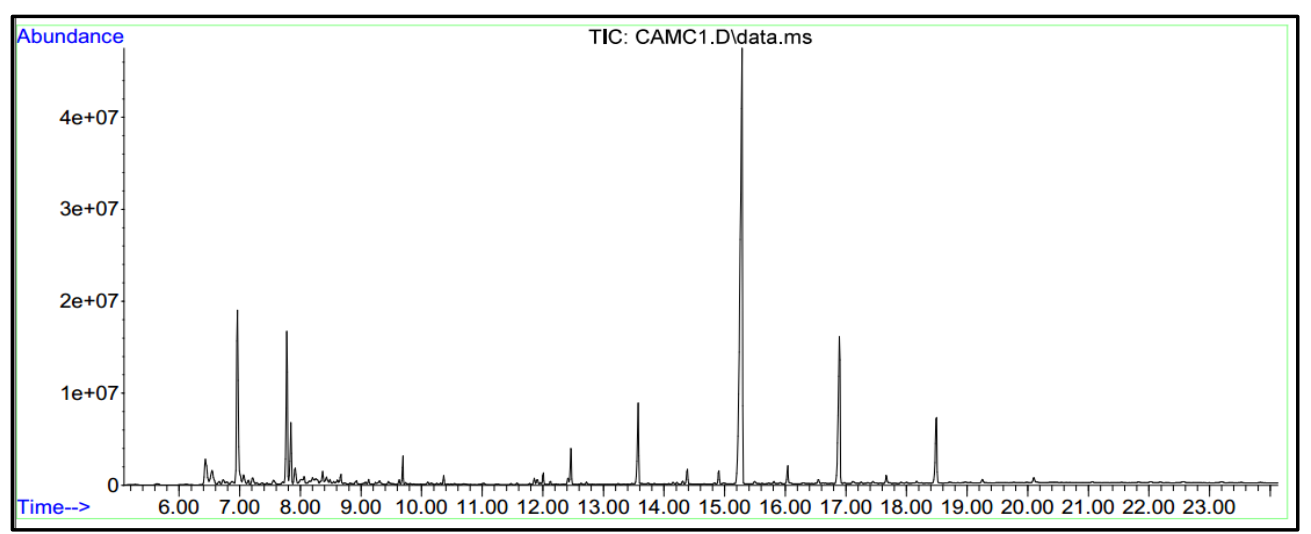

Figure 1. A representative typical GC-MS total ion current (TIC) chromatogram of essential oil isolated using microwave extraction from aerial parts (dried flowers) of C. mixtus harvested from central-northern Morocco.

Nineteen of them were in concentrations over $1 \%$, and the remaining 25 constituents were in concentrations lower than $1 \%$. The major twenty compounds $(\geq 1 \%)$, in a decreasing order, were santolina alcohol (40.7\%), germacrene D (8.9\%), $\alpha$-pinene B (5.7\%), Artemesia 
alcohol (4.3\%), (E)- $\beta$-Farnesene (4.0\%), Limonene (3.1\%), yomogi alcohol (3\%), caryophylladienol $(2.8 \%)$, camphor $(2.5 \%)$, santolina acetate $(2.2 \%)$, pinocarvone $(1.9 \%)$, $\beta$ caryophyllene (1.7\%), germacrene D-4-ol (1.6\%), epi- $\alpha$-muurolol (1.6\%), $\alpha$-cadinol $(1.4 \%)$, (E)-pinocarveol (1.3\%), epi- $\alpha$-Cadinol (1.2\%), $\delta$-cadinene $(1.1 \%)$, and bornyl acetate $(1 \%)$. From these outcomes, it seems that $C$. mixtus's EO was dominated by oxygenated monoterpenes (mainly santolina alcohol), monoterpene hydrocarbons ( $\alpha$-pinene and limonene), and sesquiterpene hydrocarbons (mostly germacrene D and (E)- $\beta$-Farnesene).

Table 1. Chemical compounds (determined using GC-MS) of essential oil (\%) isolated using microwave extraction from aerial parts (dried flowers) of $C$. mixtus collected from central-northern Morocco. Compounds are listed in the elution order. tr: trace $(<0.1 \%)$.

\begin{tabular}{|c|c|c|c|}
\hline No. & Compounds & Retention index & Relative percentage \\
\hline 1 & $\alpha$-Pinene & 939 & 5.7 \\
\hline 2 & Camphene & 954 & 0.2 \\
\hline 3 & Sabinene & 971 & 0.1 \\
\hline 4 & $\beta$-Pinene & 979 & 0.3 \\
\hline 5 & Myrcene & 982 & 0.5 \\
\hline 6 & Yomogi alcohol & 986 & 3.0 \\
\hline 7 & p-Cymene & 1025 & 0.1 \\
\hline 8 & Limonene & 1028 & 3.1 \\
\hline 9 & 1,8-Cineole & 1030 & 0.3 \\
\hline 10 & Santolina alcohol & 1037 & 40.7 \\
\hline 11 & Artemesia alcohol & 1080 & 4.3 \\
\hline 12 & Campholenal & 1121 & 0.1 \\
\hline 13 & (E)-pinocarveol & 1139 & 1.3 \\
\hline 14 & Camphor & 1146 & 2.5 \\
\hline 15 & Pinocarvone & 1155 & 1.9 \\
\hline 16 & Borneol & 1166 & 0.3 \\
\hline 17 & Santolina acetate & - & 2.2 \\
\hline 18 & Terpinen-4-ol & 1181 & 0.3 \\
\hline 19 & $\alpha$-Terpineol & 1199 & 0.2 \\
\hline 20 & Hexyl isovalerate & - & 0.1 \\
\hline 21 & Bornyl acetate & 1289 & 1 \\
\hline 22 & $\delta$-Elemene & 1340 & $\operatorname{Tr}$ \\
\hline 23 & Silphiperfolene & - & $\mathrm{Tr}$ \\
\hline 24 & (Z)-Jasmone & - & $\operatorname{Tr}$ \\
\hline 25 & Phenethyl acetate & - & 0.1 \\
\hline 26 & $\alpha$-Copaene & 1377 & 0.1 \\
\hline 27 & $\beta$-Maaliene & - & 0.4 \\
\hline 28 & $\beta$-Elemene & 1392 & 0.6 \\
\hline 29 & $\beta$-Caryophyllene & 1419 & 1.7 \\
\hline 30 & (E)- $\beta$-Farnesene & 1456 & 4 \\
\hline 31 & $\alpha$-Humulene & 1480 & 0.4 \\
\hline 32 & Germacrene D & 1485 & 8.9 \\
\hline 33 & Bicyclogermacrene & 1502 & 0.2 \\
\hline 34 & $\alpha$-Muurolene & 1503 & 0.8 \\
\hline 35 & $\delta$-Cadinene & 1520 & 1.1 \\
\hline 36 & (Z)-Nerolidol & 1536 & 0.3 \\
\hline 37 & Germacrene D-4-ol & 1570 & 1.6 \\
\hline 38 & Caryophyllene oxide & 1579 & 0.9 \\
\hline 39 & Caryophylladienol & - & 2.8 \\
\hline 40 & epi- $\alpha$-Cadinol & - & 1.2 \\
\hline 41 & epi- $\alpha$-Muurolol & - & 1.6 \\
\hline 42 & $\alpha$-Muurolol & 1639 & 0.6 \\
\hline 43 & $\alpha$-Cadinol & 1650 & 1.4 \\
\hline 44 & $\beta$-Bisabolol & 1670 & $\mathrm{Tr}$ \\
\hline Totc & \multicolumn{3}{|c|}{96.9} \\
\hline
\end{tabular}

3.1.2. Analyses of variance (ANOVA).

Table 2 summarizes the mean squares from the combined analyses of variance for yield, TPC, and TFC. From these outcomes, it has been shown that extraction technique, solvent, and 
their interaction impacted significantly, at least at $5 \%$ as a probability level, the yield, TPC, and TFC. However, the principle variability source was solvent for the three parameters. Regarding yield, solvent effects accounted for about $73 \%$ of the total variance. However, the extraction technique's effects were of lesser magnitude and explained $25 \%$ of the total variance. Similar trends were observed in TPC and TFC variability; solvent effects were the most important and explained around $95 \%$ of the total variance; meanwhile, the effects of extraction technique were less important and explained only 3\%. Finally, the extraction technique $x$ solvent interaction was also of a lesser extent since it explained around $1 \%$ of the three parameters' variance (yield, TPC, and TFC).

Table 2. Mean squares from the combined analyses of variances for yield (\%), total phenolics content (TPC, mg $\mathrm{GAE} / \mathrm{g} \mathrm{DM}$ ), and total flavonoids content (TFC, $\mathrm{mg}$ QE/g DM). $\mathrm{Df}=$ degree of freedom, GAE = Gallic acid equivalents, $\mathrm{QE}=$ Quercetin equivalents, and $\mathrm{DM}=$ Dry matter. $*$ Significant at 0.05 probability level; **

Significant at 0.01 probability level; *** Significant at 0.001 probability level.

\begin{tabular}{l|l|c|c|c|l|c|l} 
Source of variation & Df & Yield & $\boldsymbol{P}$-Value & TPC & $\boldsymbol{P}$-Value & TFC & $\boldsymbol{P}$-Value \\
\hline Extraction technique (ET) & 1 & $81.33^{* * *}$ & 0.0001 & $7.72^{* *}$ & 0.008 & $15.44^{* * *}$ & 0.0005 \\
\hline Solvent (S) & 3 & $231.58^{* * *}$ & 0.0002 & $482.24^{* * *}$ & 0.0007 & $272.17^{* * *}$ & 0.0006 \\
\hline Replicate (S) & 8 & 0.97 & 0.4813 & 0.75 & 1 & 0.68 & 1 \\
\hline ET $\times$ S & 3 & $4.51^{*}$ & 0.0333 & $4.28^{*}$ & 0.0091 & $5.69^{*}$ & 0.0091 \\
\hline Residual & 9 & 0.93 & & 0.91 & & 0.90 & \\
\hline Total (corrected) & 24 & & & & & &
\end{tabular}

3.1.3. Mean comparison of yield, TPC, and TFC for solvents and extraction techniques.

Mean values of yield, TPC, and TFC for both extractions techniques (maceration and Soxhlet) and various solvents (ethanol, ethyl acetate, methanol, and n-hexane) are given in Table 3. As evidenced in these outcomes, significant differences $(\mathrm{p}<0.05)$ were observed between both extractions techniques and among the four solvents used. Among solvents, extracts from methanol showed the highest yield, TPC, and TFC for both extractions techniques. The lowest values of yield, TPC, and TFC were achieved using n-hexane. Between extractions techniques, the Soxhlet technique displayed the highest yield (23.3\%), TPC (36.21 $\mathrm{mg} \mathrm{GAE} / \mathrm{g} \mathrm{DM})$, and TFC (26.80 mg QE/g DM) in the case of methanol. In contrast, the lowest records of these parameters were obtained using maceration and n-hexane.

Table 3. Mean values of yield (\%), total phenolics content (TPC, mg GAE/g DM), and total flavonoids content

(TFC, mg QE/g DM) for various $C$. mixtus extracts obtained by two extraction techniques (maceration and Soxhlet) using four types of solvents namely ethanol (E), ethyl acetate (EA), methanol (M), and n-hexane (H). Within the same column, values followed by the same letter are not significantly different at $5 \%$ as a probability level. $\mathrm{GAE}=$ Gallic acid equivalents, $\mathrm{QE}=$ Quercetin equivalents, and $\mathrm{DM}=$ Dry matter.

\begin{tabular}{l|l|l|l|l|l|l|l|l}
\multicolumn{2}{l|}{} & Maceration & & & & Soxhlet & \\
\hline & Yield & TPC & & TFC & Yield & TPC & TFC \\
\hline M & $21.10 \pm 0.82^{\mathrm{a}}$ & $34.70 \pm 0.60^{\mathrm{a}}$ & $24.85 \pm 0.65^{\mathrm{a}}$ & $23.30 \pm 0.80^{\mathrm{a}}$ & $36.21 \pm 1.24^{\mathrm{a}}$ & $26.80 \pm 0.80^{\mathrm{a}}$ \\
\hline E & $15.72 \pm 0.24^{\mathrm{b}}$ & $30.41 \pm 1.67^{\mathrm{b}}$ & & $16.79 \pm 0.93^{\mathrm{b}}$ & $19.76 \pm 0.81^{\mathrm{b}}$ & $33.15 \pm 1.80^{\mathrm{b}}$ & $18.43 \pm 1.41^{\mathrm{b}}$ \\
\hline EA & $9.43 \pm 0.54^{\mathrm{c}}$ & $25.17 \pm 0.62^{\mathrm{c}}$ & & $13.38 \pm 0.85^{\mathrm{c}}$ & $15.42 \pm 1.19^{\mathrm{c}}$ & $27.13 \pm 0.84^{\mathrm{c}}$ & $14.03 \pm 0.84^{\mathrm{c}}$ \\
\hline $\mathrm{H}$ & $6.69 \pm 0.39^{\mathrm{d}}$ & $15.39 \pm 0.74^{\mathrm{d}}$ & $9.04 \pm 1.30^{\mathrm{d}}$ & $9.19 \pm 0.54^{\mathrm{d}}$ & $16.39 \pm 1.75^{\mathrm{d}}$ & $11.23 \pm 1.88^{\mathrm{d}}$
\end{tabular}

Extracts from ethanol and ethyl acetate presented better scores, after methanol, of yield, TPC, and TFC. Therefore, different solvents' ability to achieve a good yield and extract bioactive compounds (TPC and TFC) was in the following order: methanol > ethanol > ethyl acetate and finally n-hexane. 
3.1.4. Mean comparison of antioxidant activities and $\mathrm{IC}_{50}$.

Antioxidant activities mean values for different extracts and ascorbic acid (control) are shown in Fig. 2. As evidenced in these outcomes, large variations were observed among antioxidant activities in the investigated extracts. Extracts from all solvents proved to reduce radical DPPH; however, ascorbic acid had the best performance in scavenging this radical. As extracts' concentration increases, there was a significant decrease $(p<0.05)$ in DPPH absorbance at $517 \mathrm{~nm}$, translated into a discoloration from purple to yellow. Indeed, at 40 $\mu \mathrm{g} / \mathrm{mL}$, ascorbic acid showed the capacity to inhibit more than half $(56.53 \%)$ of DPPH. At the same concentration $(40 \mu \mathrm{g} / \mathrm{mL})$, inhibition percentages of Me-OH, Et-OH, Ethyl Acetate, and n-hexane were $38.16,31.22,17.55$, and $11.47 \%$, respectively. Similarly, at $480 \mu \mathrm{g} / \mathrm{mL}$, ascorbic acid inhibition percentage reached $100 \%$, while Me-OH, Et-OH, Ethyl Acetate, and n-hexane were 93.36, 79.15, 75.62, and 70.48\%, respectively. Antioxidant activities seemed to follow a pattern of dose-dependent type. As compared to ascorbic acid (control), methanol was the most efficient regarding DPPH reduction, while $n$-hexane presented the smallest scavenging activity.

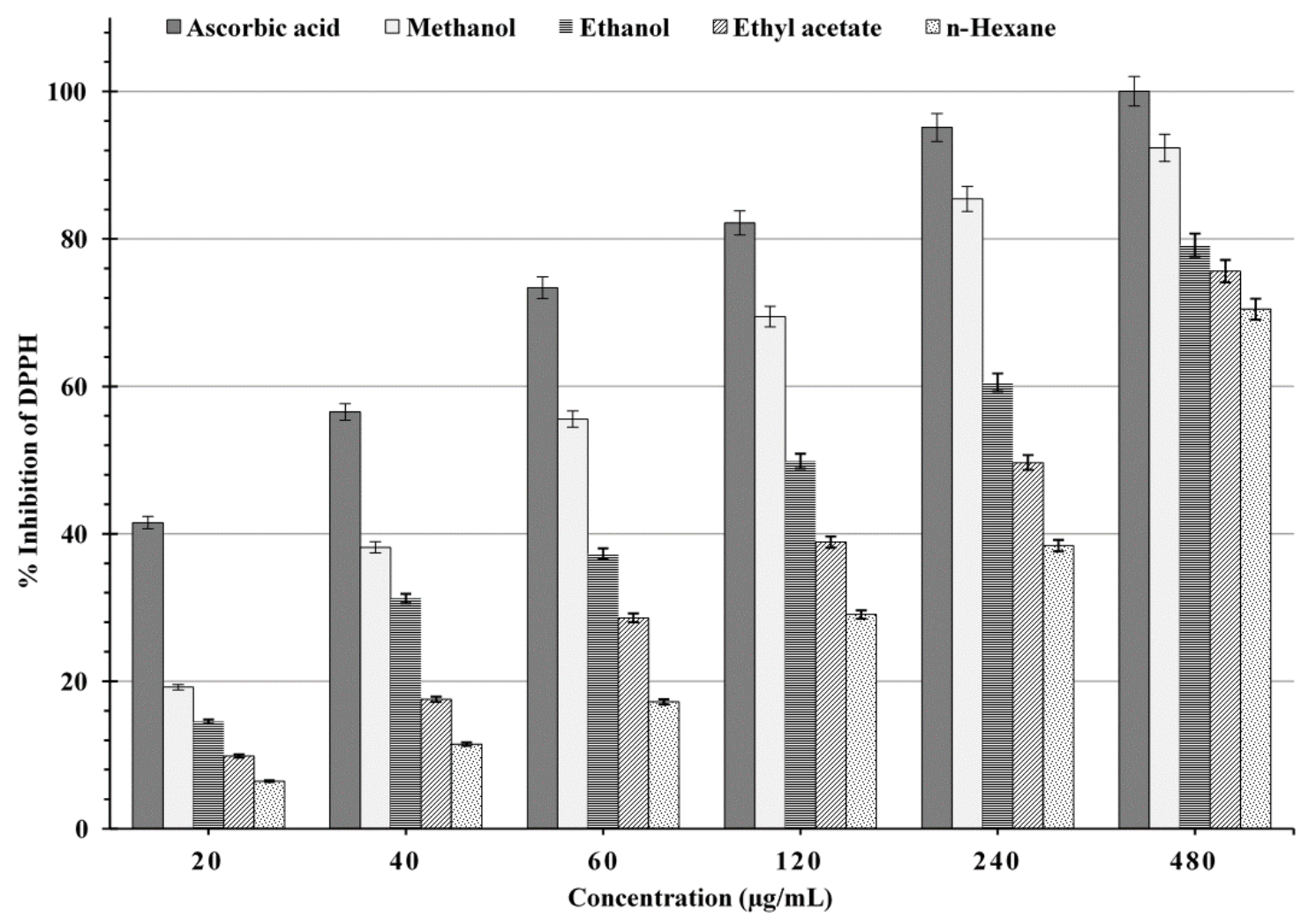

Figure 2. Antioxidant activities expressed as inhibition percentage of 2,2-diphenyl-1-picrylhydrazyl (DPPH) of various extracts (methanolic, ethanolic, ethyl acetate, and n-hexane) obtained from aerial parts (dried flowers) of

C. mixtus. Ascorbic acid was used as a control. Results are presented as mean values of three replicates.

The $\mathrm{IC}_{50}$ value is defined as the concentration of a given extract that inhibits $50 \%$ of the DPPH radical. The $\mathrm{IC}_{50}$ was determined, for various extracts, based on percentage inhibition of DPPH versus the concentrations of extracts and ascorbic acid (positive control). The Met-OH extract presented the highest antiradical activity (IC50 $=55.50 \mu \mathrm{g} / \mathrm{mL})$ followed by the Et-OH extract $\left(\mathrm{IC}_{50}=121.5 \mu \mathrm{g} / \mathrm{mL}\right)$, the ethyl acetate extract $\left(\mathrm{IC}_{50}=240.9 \mu \mathrm{g} / \mathrm{mL}\right)$, and the $\mathrm{n}$-hexane extract as the lowest antiradical power $\left(\mathrm{IC}_{50}=259 \mu \mathrm{g} / \mathrm{mL}\right)$. 
3.1.5. Mean comparison of antimicrobial activities and MIC.

Mean values of antimicrobial activities (inhibitory zone diameter, mm) and MICs $(\mu \mathrm{g} / \mathrm{mL})$ for various solvents and EOs are summarized in Table 4. As demonstrated by the Duncan's test, there were significant variations $(p<0.05)$ among the investigated parameters for various solvents and tested microbial strains. The best scores of inhibition zone diameter were achieved with methanol for all tested strains regarding antimicrobial activities. At the same time, the lowest values of this parameter were recorded in the case of $n$-hexane. Extracts from ethanol and ethyl acetate presented medium values between methanol and n-hexane. Concerning microbial strains, $C$. albicans presented the greatest values of inhibition zone diameter but only in methanol and ethanol (33.67 and $30 \mathrm{~mm}$, respectively), while S. aureus (a Gram-positive bacterium) presented the best records of this parameter with ethyl acetate (27.33 $\mathrm{mm}$ ) and n-hexane $(21.50 \mathrm{~mm})$. E. coli (a Gram-negative bacterium) was found to display the smallest inhibition zone diameter records under various solvents.

Table 4. Mean values of antimicrobial activities measured as inhibition zone diameter (IZD, mm) and minimal inhibitory concentration (MIC, in $\mu \mathrm{g} / \mathrm{mL}$ ) of various extracts (methanolic, ethanolic, ethyl acetate, and hexane) obtained by Soxhlet extraction and essential oil from C. mixtus against four microbial strains (E. coli, S. aureus, B. subtilis, and C. albicans). Values are averaged for three replicates with standard deviation. Within the same column and for the same parameter, values followed by the same letter are not significantly different at 5\% as a probability level.

\begin{tabular}{l|l|l|l|l} 
& E. coli & S. aureus & B. subtilis & C. albicans \\
\hline$I Z D($ in $m m)$ & & & & \\
\hline Methanol & $27.33 \pm 0.76^{\mathrm{a}}$ & $32.33 \pm 1.04^{\mathrm{a}}$ & $30.17 \pm 0.76^{\mathrm{a}}$ & $33.67 \pm 1.52^{\mathrm{a}}$ \\
\hline Ethanol & $23.50 \pm 2.29^{\mathrm{b}}$ & $29.83 \pm 2.28^{\mathrm{b}}$ & $26.50 \pm 1.32^{\mathrm{b}}$ & $30.00 \pm 1.80_{\mathrm{b}}$ \\
\hline Ethyl Acetate & $20.00 \pm 1.32^{\mathrm{c}}$ & $27.33 \pm 1.04^{\mathrm{c}}$ & $20.83 \pm 1.29^{\mathrm{c}}$ & $26.00 \pm 2.18^{\mathrm{c}}$ \\
\hline n-Hexane & $13.50 \pm 1.32^{\mathrm{d}}$ & $21.50 \pm 1.80^{\mathrm{d}}$ & $17.67 \pm 2.08^{\mathrm{d}}$ & $17.17 \pm 1.04^{\mathrm{d}}$ \\
\hline$M I C($ in $\mu g / m L)$ & & & & \\
\hline Methanol & $15.83 \pm 0.29^{\mathrm{d}}$ & $11.50 \pm 0.50^{\mathrm{d}}$ & $12.33 \pm 0.76^{\mathrm{c}}$ & $11.17 \pm 1.04^{\mathrm{de}}$ \\
\hline Ethanol & $17.00 \pm 0.50^{\mathrm{c}}$ & $12.33 \pm 0.29^{\mathrm{c}}$ & $13.00 \pm 0.50^{\mathrm{c}}$ & $12.67 \pm 0.29^{\mathrm{c}}$ \\
\hline Ethyl acetate & $18.00 \pm 0.50^{\mathrm{b}}$ & $15.17 \pm 0.29^{\mathrm{b}}$ & $15.50 \pm 0.50^{\mathrm{b}}$ & $14.83 \pm 0.77^{\mathrm{b}}$ \\
\hline n-Hexane & $20.83 \pm 0.76^{\mathrm{a}}$ & $17.17 \pm 0.29^{\mathrm{a}}$ & $17.50 \pm 0.50^{\mathrm{a}}$ & $16.00 \pm 0.50^{\mathrm{a}}$ \\
\hline Essential oil & $13.83 \pm 1.26^{\mathrm{e}}$ & $10.50 \pm 0.50^{\mathrm{e}}$ & $10.17 \pm 0.29^{\mathrm{d}}$ & $10.67 \pm 1.04^{\mathrm{e}}$
\end{tabular}

Concerning MICs (Table 4), extracts from various sovents as well as EO showed a wide range of variability. Also, MIC's greatest records were found in n-hexane extracts followed by ethyl acetate, ethanol, and methanol for all studied microorganisms. As compared to the four solvents used, EO showed the smallest records of MIC against all bacterial strains. It is worthy of highlighting that among microbial strains, E. coli presented the best scores of MIC (lower antimicrobial activity) for EO $(13.83 \mathrm{~mm})$ as well as methanol $(15.83 \mathrm{~mm})$, ethanol $(17 \mathrm{~mm})$, ethyl acetate $(18 \mathrm{~mm})$, and $\mathrm{n}$-hexane $(20.83 \mathrm{~mm})$. In contrast, $B$. subtilis and $S$. aureus had the lowest MIC (higher antimicrobial activity) from EO $(10.17 \mathrm{~mm})$ and ethanol $(12.33 \mathrm{~mm})$, respectively. Moreover, C. albicans was found to present the smallest values of MIC for extracts from methanol $(11.17 \mathrm{~mm})$, ethyl acetate $(14.83 \mathrm{~mm})$, and $\mathrm{n}$-hexane $(16 \mathrm{~mm})$.

\subsubsection{Principal component analysis (PCA).}

PCA was used as a multivariate statistical method to discriminate among solvents used for extraction and extractions techniques based on various dependant variables (yield, TPC, TFC, MIC, and antimicrobial activities). The two first principal components (PCs) were retained because they explained that over $99 \%$ of the total variability. 

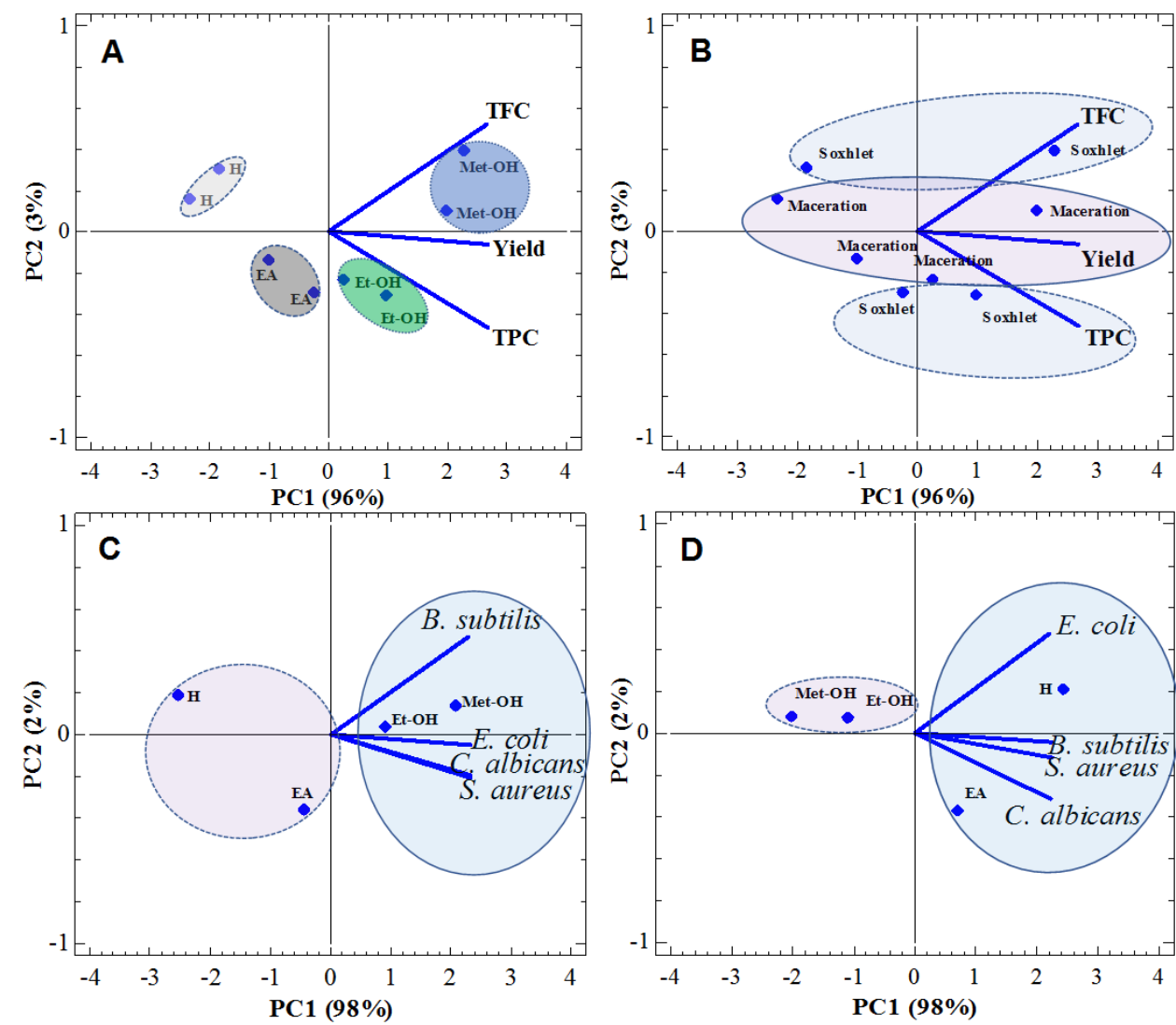

Figure 3. Principal component analysis (PCA) projections on PC1 and PC2. Eigenvalues are symbolized as blue segments representing parameters that most affect each principal component. Plotted points are mean values of each studied parameter of various extracts (methanolic, ethanolic, ethyl acetate, and n-hexane) obtained from aerial parts (dried flowers) of $C$. mixtus. $\mathrm{H}=\mathrm{n}$-hexane, Met-OH = Methanol, Et-OH = Ethanol, EA = Ethyl Acetate, $\mathrm{TPC}=$ total phenolics content, $\mathrm{TFC}=$ total flavonoids content.

Points plotted on the surface determined by axis 1, and 2 (Fig. 3A) are related to solvents, which seem to be distributed along with the first component (PC1). Toward the positive side of PC1, Me-OH and Et-OH interacted with higher yield scores, TPC, and TFC. In contrast, both n-hexane $(\mathrm{H})$ and ethyl acetate (EA) were projected on the negative side of PC1 with low records of these parameters. Similarly, points plotted on the plan determined by axis 1 and 2 were linked to extraction techniques (Fig. 3B). It seems that both techniques were distributed along with the second component (PC2), Soxhlet interacted with both TPC and TFC on the negative and positive sides of $\mathrm{PC} 2$, respectively.

Fig. 3C presents the distribution of solvents (independent variables) versus antimicrobial activities as dependant variables on the surface determined by PC1 and PC2. From these outcomes, solvents were distributed according to PC1 (98\%). Both Me-OH and Et$\mathrm{OH}$ were associated with higher records of antimicrobial activities for all tested strains. In contrast, $\mathrm{H}$ and EA together were associated with negatives values of PC2 and antimicrobial activities. Finally, Fig. 3D summarizes interactions between solvents as independent variables on one hand and MIC from all tested strains as dependant variables on the other hand. Solvents seemed to be plotted following the first component PC1, with over $98 \%$ of the total variability. Both extracts from $\mathrm{H}$ and EA were linked with higher MIC records on the positive side of PC1. On the contrary, extracts from $\mathrm{Me}-\mathrm{OH}$ and $\mathrm{Et}-\mathrm{OH}$ interacted, on the negative values of $\mathrm{PC} 2$, with smaller MIC values. 


\subsection{Discussion.}

In this work, we reported EO chemical profiling, antioxidants, and antimicrobial activities of flower extracts of Moroccan chamomile (C. mixtus). It is well documented that chemical composition depends upon several factors like environmental conditions under which plants are grown, genetic differences, the plant part used for EOs isolation, among others [21]. In addition, other parameters, such as harvest season and extraction methods, widely affect the extraction yield of the EOs/extracts, their composition, and, therefore, their bioactivity [37].

A literature review shows that EO yield varies widely within the same plant species depending upon several factors such as plant parts used for extraction, phenological stage, the geographical area under which plants are grown, harvest season, extraction techniques, and conditions like temperature, duration, among others [38,39]. These factors impact not only EO yield but also the chemical composition. In our results, EO yield was found to be $0.79 \pm 0.06$ (Microwave) and $0.53 \pm 0.09 \%$ (Clevenger). Solvent-free microwave extraction is based on the combination of low microwave heating and distillation that is performed at atmospheric pressure. The advantages of this method over hydrodistillation include rapidity in attaining the extraction temperature of $100^{\circ} \mathrm{C}$ for the first $\mathrm{EO}$ droplet, the high yield of $\mathrm{EO}$, the lower energy requirements, and the high purity of the oil extracted [26]. EO yield values, found in our results, were in agreement with yield reports for $C$. mixtus collected from several areas in Morocco and abroad [21,40-43]. Elouaddari et al. (2015) [16] investigated $C$. mixtus EO from leaves and flowers. They found that EO is mainly concentrated in flowers. As recently reviewed by Elouaddari et al. (2019a) [21], C. mixtus EO yields vary in the range 0.06-1.56\%.

As for yield, EO chemical composition varies widely qualitatively and quantitively. It is well established that EOs are complex mixtures; the chemical composition within the same species vary widely. A total of 264 components were identified, in the literature, in C. mixtus EO as outlined in Elouaddari et al. (2019b) [24], with the predominance of the oxygenated monoterpenes. As highlighted in the results section, we identified and quantified 44 compounds. The five major components were the following: Santolina alcohol was the major component (40.7\% of the chemical composition), followed by Germacrene D (8.9\%), $\alpha$-Pinene (5.7\%), Artemisia alcohol (4.3\%), (E)- $\beta$-Farnesene (4\%). Several authors reported similar results regarding the major component of EO isolated from C. mixtus flowers. Indeed, Zrira et al. (2007) [40] found that santolina alcohol as the major component EO isolated from various plant parts (whole plant, leaves, flowers, and stems) collected from western Morocco, with flowers having the score (40.2\%). Likewise, Toulemonde and Beauverd (1984) [44], LisBalchin et al. (1998) [45], Satrani et al. (2007) [46], and Darriet et al. (2012) [41] found similar chemical composition to our findings with the dominance of santolina alcohol. On the contrary, other authors found that this alcohol is present in smaller quantities or even absent $[20,21,42,43]$. C. mixtus' EO from eastern Morocco (Oujda) was found to have trans- $\beta$ farnesene as the main component (35.5-50.5\%) as outlined in Elouaddari et al. (2013) [42] and Elouaddari et al. (2014) [43]. 2-Methyl-2- trans-butenyl methacrylate (32.0-35.2\%) was the main constituent for samples collected in western Morocco (Bouznika) as demonstrated by several reports [21,42,43]. Elouaddari et al. (2013) [42], while investigating EO' composition from various areas in western Morocco, they found that camphor (14.4-29\%) was the main constituent together with trans- $\beta$-farnesene (8.3\%), and 2-tridecanone $(21.5 \%)$. It is worthy to note that the occurrence of some oxygenated monoterpenes (santolina alcohol, Artemisia alcohol, and yomogi alcohol) were also described in similar amounts in other species belonging 
to Asteraceae family such as Achillea ageratum [47]. These differences, within the same species, highlighted in the EO composition of $C$. mixtus flowers, could be attributed to several factors such as pedo-climatic differences, plant phenology, extraction technique, and conditions.

As presented in the results section, significant differences were found among solvents and between extraction methods regarding extract yields, TPC, and TFC. These outcomes were consistent with published literature for chamomiles and other species [48-51]. Extracts from $\mathrm{Me}-\mathrm{OH}$ and Et-OH performed better than n-hexane and ethyl acetate. However, ethanol is preferred to extract bioactive compounds, mainly due to its lower toxicity [52]. Similar trends were outlined in several reports on Chamomiles and other species [33,34,49,50]. As demonstrated by previous similar works, $\mathrm{Me}-\mathrm{OH}$ and Et-OH are the better solvents in extracting phenolic compounds from chamomile extracts thanks to their higher polarity and good solubility of phenolic components contained in plant materials as demonstrated by Roby et al. (2013) [49]. Likewise, in a study involving thirteen chemotypes belonging to German chamomile (Matricaria recutita L.) collected in South-central Italy, Formisano et al. (2015) [50] found similar values of yield, TPC, and TFC for methanolic extracts achieved maceration.

Moreover, as compared to Soxhlet extraction, maceration allowed lower records of yield extracts, TPC, and TFC in agreement with other works [53,54]. In this context, as explained in Markom et al. (2007) [55], Soxhlet extraction carried out at solvents' boiling temperature, the viscosity and surface tension are lower than those at lower temperatures (maceration). Therefore, the solvent can reach, far more efficiently, the active sites within the solid matrix, thus promoting better solubilization resulting in a higher yield and phenolics content when compared to maceration. However, extraction via maceration has several advantages over Soxhlet. One of the most important advantages of maceration is conserve thermolabile compounds' integrity thanks to the low extraction temperature and saving time, material, and the constituents' diversity [56].

Concerning antimicrobial activities, wide variations in terms of inhibition zone diameter and MIC were highlighted among microbial strains on one hand and various extracts on the other hand. Mean values reported in our work were comparable to those found in the literature for $C$. mixtus collected in Morocco and abroad [24,41,42]. As highlighted in the results' section, the most important records of inhibition zone diameter were records in yeast strain (C. albicans), followed by Gram-positive bacteria (B. subtilis and S. aureus), and the Gram-negative one (E. coli) especially for extracts from Me-OH and Et-OH. Such findings agreed with other published works [24,57], who found that yeast strains show their superiority over both kinds of bacteria (Gram-positive and Gram-negative) for both EOs and methanolic extracts.

Most works carried out regarding the antimicrobial activities of EOs have demonstrated Gram-positive bacteria to be more sensitive than Gram-negative bacteria. This sensitivity difference is due to the presence of an outer membrane containing hydrophilic lipopolysaccharides encompassing the bacterial peptidoglycan layer in Gram-negative bacteria, which acts as a barrier towards macromolecules as well as hydrophobic compounds and limits the diffusion of hydrophobic compounds into the bacterium cytoplasm [58,59]. As for microbial strains, significant differences in antimicrobial activities were outlined among solvents with the superiority of $\mathrm{Me}-\mathrm{OH}$ and Et-OH. Following our results, Elshobary et al. (2020) [60] found that low polarity solvents such as hexane show lower activities mainly due to the difference in the solubility of the bioactive compound [61]. 
Results of MICs confirmed the effectiveness of various extracts and EO against studied microbial strains. For solvents, lower MIC values were found in Met-OH and Et-OH extracts, suggesting that their biochemical content has strong antimicrobial activities since they can inhibit microbial growth even at low concentrations. Effects of various solvents (with different polarities) and different extraction techniques on the chemical composition and biological activities have been investigated in German chamomile extracts, showing that these parameters can deeply modify EO and extract composition and MIC against several pathogen strains $[62,63]$. These works' outcomes demonstrated that higher polarity solvents are more effective in extracting bioactive compounds and, therefore, showing the ability to inhibit microbial growth at lower concentrations (lower MIC). A similar trend was observed for $\mathrm{IC}_{50}$; compared to n-hexane and ethyl acetate, extracts from Met-OH and Et-OH reduced 50\% of DPPH at lesser concentrations. According to Roby et al. (2013) [49], IC 50 is the moles of phenolic compounds divided by moles of DPPH necessary to reduce by $50 \%$ the absorbance of DPPH. The lower the $\mathrm{IC}_{50}$, the higher is the antioxidant activity. The difference in antioxidant activities among solvents observed in our results were consistent with Yazdani et al. (2019) [64].

Results regarding the difference between solvents and extractions techniques were graphically elucidated using PCA. This multivariate statistical approach is widely used as a discriminative tool in many fields such as chemometric and agronomy [65-67]. In our previous works, PCA was successfully used to separate environments and genotypes based on fruit quality traits, including phenolics content [68-71]. As stated in the results' section, the first component ( $\mathrm{PC1}=96 \%$, Fig. 3A), separated solvents confirming, thus, the ANOVA outcomes that solvent was the main variability source. A similar trend was observed in the case of antimicrobial activity, and MIC (Fig. 3C and D), that variability in these data was attributed, to a large extent, to solvents PC1 $(98 \%)$ followed by microbial strains (PC2 $=2 \%)$.

The observed biological activities could be ascribed to the main constituents such as santolina alcohol, germacrene D, and $\alpha$-pinene, as suggested in several reports $[20,47,72,73]$. Furthermore, synergistic effects of other minor constituents cannot be disregarded, as discussed in El Abdouni Khayari et al. (2016) [47].

The outcomes of the present work demonstrated that EO and various extracts from $C$. mixtus display good antioxidant and antimicrobial activities. The production of such EO and bioactive components from $C$. mixtus and their use as potential natural preservatives could be of important economic value. However, supplementary investigations involving more detailed in vitro and in vivo assays seem to be needed to determine which components of the $\mathrm{EO}$ or extracts give the best biological activities. Overall, this paper presents valuable information regarding the composition and antimicrobial activity of $C$. mixtus $\mathrm{EO}$ and their various extracts from northern Morocco. Besides its traditional uses, C. mixtus might be explored for eventual applications in functional foods and nutraceuticals.

\section{Conclusions}

Better records of yield, TPC, TFC, and associated biological activities were achieved with $\mathrm{Me}-\mathrm{OH}$ (higher polarity), especially when combined with Soxhlet as an extraction technique. These outcomes were better elucidated by PCA, which allowed clear discrimination of solvents and extraction techniques mainly through the first two components accounting for over $98 \%$ of the total data variability. EO and various extracts from C. mixtus flowers showed potential antimicrobial and antioxidant activities linked to an essential biochemical richness. The three main compounds (> 5\%) found in C. mixtus EO were santolina alcohol (40.7\%), 
followed by germacrene D (8.9\%), and $\alpha$-pinene (5.7\%). Wide variations in C. mixtus EO were found in peer-reviewed literature depending on several factors (geographical area, phenology, techniques used, among others). Therefore, EO producers must be aware of these variations. Results of our study suggested the exploitation of $C$. mixtus flower EO and extracts as natural preservatives to enhance the shelf life of herbal formulations as well as nutraceuticals.

\section{Funding}

This research received no external funding.

\section{Acknowledgments}

\section{The authors would like to thank Dr. Taha El Kamli (Food and Nutritional Transition Team (ETAN), Laboratory of Biological Tests, Ibn Tofail University, Morocco) for the kind technical assistance.}

\section{Conflicts of Interest}

The authors declare no conflict of interest.

\section{References}

1. Jugreet, B.S.; Mahomoodally, M.F. Essential oils from 9 exotic and endemic medicinal plants from Mauritius shows in vitro antibacterial and antibiotic potentiating activities. $S$ Afr J Bot 2020, 132, 355-362, https://doi.org/10.1016/j.sajb.2020.05.001.

2. Tanwar, J.; Das, S.; Fatima, Z.; Hameed, S. Multidrug resistance: an emerging crisis. Interdiscip Perspect Infect Dis 2014, 2014, https://doi.org/10.1155/2014/541340.

3. Reardon, S. Antibiotic resistance sweeping developing world: bacteria are increasingly dodging extermination as drug availability outpaces regulation. Nature 2014, 509, 141-143, https://doi.org/10.1038/509141a.

4. O'neill, J.I.M. Antimicrobial resistance: tackling a crisis for the health and wealth of nations. Rev Antimicrob Resist 2014, 20, 1-16.

5. Mendelson, M. Role of antibiotic stewardship in extending the age of modern medicine. S Afr Med J 2015, 105, 414-419, https://doi.org/10.7196/SAMJ.9635.

6. Zgoda, J.R.; Porter, J.R.A. convenient microdilution method for screening natural products against bacteria and fungi. Pharm Biol 2001, 39, 221-225, https://doi.org/10.1076/phbi.39.3.221.5934.

7. Bouyahya, A.; Lagrouh, F.; El Omari, N.; Bourais, I.; El Jemli, M.; Marmouzi, I.; Salhi, N.; Faouzi, M.E.A.; Belmehdi, O.; Dakka, N.; Bakri, Y. Essential oils of Mentha viridis rich phenolic compounds show important antioxidant, antidiabetic, dermatoprotective, antidermatophyte and antibacterial properties. Biocatal Agric Biotechnol 2020, 23, https://doi.org/10.1016/j.bcab.2019.101471.

8. Saleem, H.; Htar, T.T.; Naidu, R.; Ahmad, I.; Zengin, G.; Ahmad, M.; Ahemad, N. Investigations into the therapeutic effects of aerial and stem parts of Buxus papillosa CK Schneid: In vitro chemical, biological and toxicological perspectives. $J$ Pharm Biomed Anal 2019, 166, 128-138, https://doi.org/10.1016/j.jpba.2019.01.007.

9. Llorent-Martinez, E.J.; Ruiz-Riaguas, A.; Sinan, K.I.; Bene, K.; Cordova, M.L.F.; PicotAllain, C.; Mahomoodally, F.; Saleem, H.; Zengin, G. Exploring chemical profiles and bioactivities of Harungana madagascariensis Lam. ex Poir. leaves and stem bark extracts: A new source of procyanidins. Anal Lett 2019, 53, 399-412, https://doi.org/10.1080/00032719.2019.1653903.

10. Nisar, B.; Sultan, A.; Rubab, S.L. Comparison of medicinally important natural products versus synthetic drugs-a short commentary. Nat Prod Chem Res 2017, 6, 308, https://doi.org/10.4172/2329-6836.1000308.

11. Gibbons, S. Anti-staphylococcal plant natural products. Nat Prod Rep 2004, 21, 263-277, https://doi.org/10.1039/b212695h.

12. Rankou, H.; Culham, A.; Jury, S.L.; Christenhusz, M. The endemic flora of Morocco. Phytotaxa 2013, 78, 1-69, https://doi.org/10.11646/phytotaxa.78.1.1.

13. Bakha, M.; Al Faiz, C.; Daoud, M.; El Mtili, N.; Aboukhalid, K.; Khiraoui, A.; Machon, N.; Silijak Yakovlev, S. Genome size and chromosome number for six taxa of Origanum genus from Morocco. Bot Lett 2017, 164, 361-370, https://doi.org/10.1080/23818107.2017.1395766.

14. Teixeira da Silva, J.A. Mining the essential oils of the Anthemideae. Afr J Biotechnol 2004, 3, 706-720. 
15. Quezel, P.; Santana, S. Nouvelle flore de l'Algérie et des régions désertique méridionales. Tome II.; Editions centre national de la recherche scientifique: Paris, France, 1963.

16. Elouaddari, A.; El Amrani, A.; Jamal Eddine, J. Effect of the Parts of Plant Material (Flowers and Leaves) on Essential Oil Chemical Composition of Ormenis mixta from Morocco. J Essent Oil Bear Pl 2015, 18, 398-408.

17. Benjilali, B.; Zrira, S. Plantes aromatiques et médicinales, Atouts du secteur et exigences pour une valorisation durable. Actes éditions Institut agronomique et vétérinaire Hassan-II: Rabat, Morocco, 2005.

18. Quarenghi, M.V.; Tereschuk, M.L.; Baigori, B.D.; Abdala, L.R. Antimicrobial activity of flowers from Anthemis cotul. Fitoterapia 2000, 71, 710-712, https://doi.org/10.1016/S0367-326X(00)00229-X.

19. Haddad, P.S.; Depot, M.; Settaf, A.; Chabli, A.; Cherrah, Y. Comparative study on the medicinal plants most recommended by traditional practitioners in Morroco and Canada. J Herbs Spices Med Plants 2003, 10, 2545, https://doi.org/10.1300/J044v10n03_04.

20. Wanner, J.; Schmidt, E.; Bail, S.; Jirovetz, L.; Buchbauer, G.; Gochev, V.; Girova, T.; Atanasova, T.; Stoyanova, A. Chemical composition, olfactory evaluation and antimicrobial activity of selected essential oils and absolutes from Morocco. Nat Prod Commun 2010, 5, 1349-1354, https://doi.org/10.1177/1934578X1000500903.

21. Elouaddari, A.; El Amrani, A.; Cayuela-Sánchez, J.A.; Ould Bellahcen, T.; Zouiten, A.; Jamal Eddine, J. Chemical Composition and Biological Activities of the Cladanthus mixtus Essential Oil: A Review. Anal Chem Lett 2019a, 9, 649-663, https://doi.org/10.1080/22297928.2019.1682665.

22. Engelmeier, D.; Hadacek, F.; Hofer, O.; Lutz-Kutschera, G.; Nagl, M.; Wurz, G.; Greger, H. Antifungal 3Butylisocoumarins from Asteraceae-Anthemideae. $J$ Nat Prod 2004, 67, 19-25, https://doi.org/10.1021/np0301339.

23. Abdel-Gaber, A.M.; Abd-El-Nabey, B.A.; Sidahmed, I.M.; El-Zayady, A.M.; Saadawy, M. Inhibitive action of some plant extracts on the corrosion of steel in acidic media. Corros Sci 2006, 48, 2765-2779, https://doi.org/10.1016/j.corsci.2005.09.017.

24. Elouaddari, A.; Elamrani, A.; Moutia, M.; Oubrim, N.; Habti, N.; Jamal Eddine, J. Chemical Composition and Evaluation of Antioxidant, Antimicrobial and Cytotoxic Activities of Moroccan Cladanthus mixtus Essential Oil and Extracts. J Essent Oil Bear Pl 2019b, 22, 1450-1466, https://doi.org/10.1080/0972060X.2019.1691059.

25. Pizzale, L.; Bortolomeazzi, R.; Vichi, S.; Überegger, E.; Conte, L.S. Antioxidant activity of sage (Salvia officinalis and S. Fructicosa) and oregano (Origanum onites and O. inderscedens) extracts related to their phenolic compound content. J Sci Food Agr 2002, 82, 1645-1651, https://doi.org/10.1002/jsfa.1240.

26. Lucchesi, M.E.; Chemat, F.; Smadja, J. Solvent-free microwave extraction of essential oil from aromatic herbs: comparison with conventional hydrodistillation. J Chromatogr A 2004, 1043, 323-327, https://doi.org/10.1016/j.chroma.2004.05.083.

27. Bousbia, N.; Vian, M.A.; Ferhat, M.A.; Petitcolas, E.; Meklati, B.Y.; Chemat, F. Comparison of two isolation methods for essential oil from rosemary leaves: Hydrodistillation and microwave hydrodiffusion and gravity. Food chem 2009, 114, 355-362, https://doi.org/10.1016/j.foodchem.2008.09.106.

28. Jennan, S.; Fouad, R.; Nordine, A.; Farah, A.; Bennani, B.; Moja, S.; Greche, H.; Mahjoubi, F. Chemical Composition and Antibacterial Screening of Aerial Parts of Essential Oils of Three Satureja species (Satureja briquetti, Satureja atlantica and Satureja alpina) Growing Wild in the Middle Atlas Mountains of Morocco. J Essent Oil Bear 2018, 21, 741-748, https://doi.org/10.1080/0972060X.2018.1486230.

29. Talbaoui, A.; El amdaoui, H.; El Moussaouiti, M.; Aneb, M.; Amzazi, S.; Bakri, Y. GC-MS analysis and antibacterial activity of hydro-distitllation oil from Tetraclinis articulata wood grown in Khemisset (Morocco). J Indian Acad Wood Sci 2016, 13, 114-117, https://doi.org/10.1007/s13196-016-0173-7.

30. Singleton, V.L.; Orthofer, R.; Lamuela-Raventos, R.M. Analysis of total phenols and other oxidation substrates and antioxidants by means of folin-ciocalteu reagent. Methods in Enzymol 1999, 299, 152-178, https://doi.org/10.1016/S0076-6879(99)99017-1.

31. Dehpour, A.A.; Ibrahimzadeh, M.A.; Fazel, N.S.; Mohammad, N.S. Antioxidant activity of the methanol extract of Ferula asafoetida and its essential oil composition. Grasas Aceites 2009, 60, 405-412, https://doi.org/10.3989/gya.010109.

32. Brand-Williams, W.; Cuvelier, M.E.; Berset, C. Use of a Free Radical Method to Evaluate Antioxidant Activity. LWT-Food Sci Technol 1995, 28, 25-30, https://doi.org/10.1016/S0023-6438(95)80008-5.

33. Zeroual, A.; Eloutassi, N.; Chaouch, M.; Chaqroune, A. Antimicrobial, antioxidant activity, and chemical composition of Origanum compactum benth from taounate province, north Morocco. Asian J Pharm Clin Res 2020, 13, 126-131, https://doi.org/10.22159/ajpcr.2020.v13i3.36319.

34. Zeroual, A.; Eloutassi, N.; Sakar, E.H.; Nechad, I.; Louaste, B.; Lahkimi, A.; Chaouch, M.; Chaqroune, A. Antimicrobial and antioxidant activities of crude extracts and essential oils from two thyme species: Thymus vulgaris and Thymus hyemalis from northern Morocco. Int J Biosci 2018, 12, 391-399.

35. Balouiri, M.; Sadiki, M.; Ibnsouda, S.K. Methods for in vitro evaluating antimicrobial activity: A review. $J$ Pharm Analysis 2016, 6, 71-79, https://doi.org/10.1016/j.jpha.2015.11.005. 
36. Prudent, D.; Perineau, F.; Bessiere, J. M.; Michel, G.M.; Baccou, J.C. Analysis of the essential oil of wild oregano from Martinique (Coleus aromaticus Benth.) evaluation of its bacterioatatic and fungistatic properties. J Essent Oil Res 1995, 7, 165-173, https://doi.org/10.1080/10412905.1995.9698492.

37. Salamon, I. Effect of the Internal and External Factors on Yield and Qualitative Characteristics of Chamomile Essential Oil. Ist IS on Chamomile Research, Development and Production. Acta Hortic 2007, 749, 45-64, https://doi.org/10.17660/ActaHortic.2007.749.3.

38. Borsato, A.V.; Doni-Filho, L.; Rakocevic, M.; Côcco, L.C.; Paglia, E.C. Chamomile essential oils extracted from flower heads and recovered water during drying process. J Food Process Preserv 2009, 33, 500-512, https://doi.org/10.1111/j.1745-4549.2008.00271.x.

39. Stankov, S.; Fidan, H.; Stefanova, G.; Kostova, I.; Damyanova, S.; Dimitrova-Dyulgerova, I.; Ercisli, S.; Stoyanova, A. Chemical Composition and Antimicrobial Activity of Essential Oil from Aerial Part (Leaves and Fruit) of Eucalyptus gomphocephala DC. J Essent Oil Bear Pl 2020, 23, 204-212, https://doi.org/10.1080/0972060X.2020.1727365.

40. Zrira, S.; Menut, C.; Bessiere, J.M.; Benjilalii, B. Chemical Composition of the Essential Oils of Moroccan Ormenis mixta (L.) Dumort. ssp. Multicaulis. J Essent Oil Bear Plants 2007, 10, 378-385, https://doi.org/10.1080/0972060X.2007.10643570.

41. Darriet, F.; Bendahou, M.; Costa, J.; Muselli, A. Chemical compositions of the essential oils of the aerial parts of Chamaemelum mixtum (L.) Alloni. J Agric Food Chem 2012, 60, 1494-1502, https://doi.org/10.1021/jf203872z.

42. Elouaddari, A.; El Amrani, A.; Jamal Eddine, J.; Isabel, A.; Correia, D.; Barroso, J.G.; Pedro, L.G.; Figueiredoet, A.C. Yield and chemical composition of the essential oil of Moroccan chamomile [Cladanthus mixtus (L.) Chevall.] growing wild at different sites in Morocco. Flav Frag J 2013, 28, 360-366, https://doi.org/10.1002/ffj.3146.

43. Elouaddari, A.; El Amrani, A.; Jamal Eddine, J. Intraspecific variability of the essential oil of Cladanthus mixtus from Morocco. Nat Prod Commun 2014, 9, 133-136, https://doi.org/10.1177/1934578X1400900137.

44. Toulemonde, B.; Beauverd, D. Contribution à l'étude d'une camomille sauvage du Maroc: L'huile essentielle d Ormenis mixta. Parfums Cosmet Aromes 1984, 60, 65-67.

45. Lis-Balchin, M.; Deans, S.G.; Eaglesham, E. Relationship between bioactivity and chemical composition of commercial essential oils. Flavour Fragr J 1998, 13, 98-104, https://doi.org/10.1002/(SICI)10991026(199803/04)13:2<98::AID-FFJ705>3.0.CO;2-B.

46. Satrani, B.; Ghanmi, M.; Frah, A.; Aafi, A.; Fougrach, H.; Bourkhiss, B.; Bousta, D.; Talbi, M. Composition Chimique Et Activité Antimicrobienne De L'huile Essentielle De Cladanthus Mixtus. Bull Soc Pharm Bordeaux 2007, 146, 85-96.

47. Khayari, E.A.M.; Jamali, C.A.; Kasrati, A.; Leach, D.; Markouk, M.; Abbad, A. Antibacterial activity of essential oils of some moroccan aromatic herbs against selected food-related Bacteria. J Essent Oil Bear Plants 2016, 19, 1075-1085, https://doi.org/10.1080/0972060X.2015.1004123.

48. Annegowda, H.V.; Tan, P.Y.; Mordi, M.N.; Ramanathan, S.; Hamdan, M.R.; Sulaiman, M.H.; Mansor, S.M. TLC-bioautography-guided isolation, HPTLC and GC-MS-assisted analysis of bioactives of Piper betle leaf extract obtained from various extraction techniques: In vitro evaluation of phenolic content, antioxidant and antimicrobial activities. Food Anal Methods 2013, 6, 715-726, https://doi.org/10.1007/s12161-0129470-y.

49. Roby, M.H.H.; Sarhan, M.A.; Selim, K.A.H.; Khalel, K.I. Antioxidant and antimicrobial activities of essential oil and extracts of fennel (Foeniculum vulgare L.) and chamomile (Matricaria chamomilla L.). Ind Crops Prod 2013, 44, 437-445, https://doi.org/10.1002/ffj.1929.

50. Formisano, C.; Delfine, S.; Oliviero, F.; Tenore, G.C.; Rigano, D.; Senatore, F. Correlation among environmental factors, chemical composition andantioxidative properties of essential oil and extracts of chamomile (Matricaria chamomilla L.) collected in Molise (South-central Italy). Ind Crops Prod 2015, 63, 256-263, https://doi.org/10.1016/j.indcrop.2014.09.042.

51. Albayrak, S.; Atasagun, B.; Aksoy, A. Comparison of phenolic components and biological activities of two Centaurea sp. obtained by three extraction techniques. Asian Pac J Trop Med 2017, 10, 599-606, https://doi.org/10.1016/j.apjtm.2017.06.010.

52. Karadeniz, F.; Burdurlu, H. S.; Koca, N.; Soyer, Y. Antioxidant activity of selected fruits and vegetables grown in Turkey. Turk J Agric 2005, 29, 297-303.

53. Mezzomo, N.; Mileo, B.R.; Friedrich, M.T.; Martínez, J.; Ferreira, S.R.S. Supercritical fluid extraction of peach (Prunus persica) almond oil: process yield and extract composition. Bioresour Technol 2010, 101, 5622-5632, https://doi.org/10.1016/j.supflu.2009.07.008.

54. Lasta, H.F.B.; Lentz, L.; Mezzomo, N.; Ferreira, S.R.S. Supercritical $\mathrm{CO}_{2}$ to recover extracts enriched in antioxidant compounds from beetroot aerial parts. Biocatal Agric Biotechnol 2019, 19, https://doi.org/10.1016/j.bcab.2019.101169.

55. Markom, M.; Hasan, M.; Daud, W.R.W.; Singh, H.; Jahim, J.M. Extraction of hydrolysable tannins from Phyllanthus niruri Linn.: effects of solvents and extraction methods. Sep Purif Technol 2007, 52, 487-496, https://doi.org/10.1016/j.seppur.2006.06.003. 
56. Wu, C.; Wang, F.; Liu, J.; Zou, Y.; Chen, X. A comparison of volatile fractions obtained from Lonicera macranthoides via different extraction processes: Ultrasound, microwave, Soxhlet extraction, hydrodistillation, and cold maceration. Int Med Res 2015, 4, 171-177, https://doi.org/10.1016/j.imr.2015.06.001.

57. Kanatt, S.R.; Siddiqui, A.; Chawla, S.P. Antioxidant/antimicrobial potential of Emblica officinalis gaertn and its application as a natural additive for shelf life extension of minced chicken meat. Biointerface Res Appl Chem 2018, 8, 3344-3350.

58. Yap, P.S.X.; Krishnan, T.; Chan, K.G.; Lim, S.H. Antibacterial mode of action of Cinnamomum verum bark essential oil, alone and in combination with piperacillin, against a multi-drug-resistant Escherichia coli strain. J Microbiol Biotechnol 2015, 25, 1299-1306, https://dx.doi.org/10.4014/jmb.1407.07054.

59. Yap, P.S.X.; Krishnan, T.; Yiap, B.C.; Hu, C.P.; Chan, K.G.; Lim, S.H.E. Membrane disruption and antiquorum sensing effects of synergistic interaction between Lavandula angustifolia (lavender oil) in combination with antibiotic against plasmidconferred multidrugresistant Escherichia coli. J Appl Microb 2014, 116, 1119-1128, https://doi.org/10.1111/jam.12444.

60. Elshobary, M.; El-Shenody, R.; Ashour, M.; Zabed, H.M.; Qi, X. Antimicrobial and antioxidant characterization of bioactive components from Chlorococcum minutum, a newly isolated green microalga. Food Bioscience 2020, 35, https://doi.org/10.1016/j.fbio.2020.100567.

61. Patil, A.G.; Koli, S.P.; Patil, D.A.; Phatak, A.V. Evaluation of extraction techniques with various solvents to determine extraction efficiency of selected medicinal plants. Int J Pharm Sci Res 2012, 3, 2607-2612.

62. Cvetanović, A.; Švarc-Gajić, J.; Mašković, P.; Savić, S.; Nikolić, L. Antioxidant and biological activity of chamomile extracts obtained by different techniques: perspective of using superheated water for isolation of biologically active compounds. Ind Crops Prod 2015, 65, 582-591, https://doi.org/10.1016/j.indcrop.2014.09.044.

63. Metrouh-Amir, H.; Duarte, C.M.; Maiza, F. Solvent effect on total phenolic contents, antioxidant, and antibacterial activities of Matricaria pubescens. Ind Crops Prod 2015, 67, 249-256, https://doi.org/10.1016/j.indcrop.2015.01.049.

64. Yazdani, E.; Talebi, M.; Zarshenas, M.M.; Moein, M. Evaluation of possible antioxidant activities of barberry solid formulation, a selected formulation from traditional persian medicine (tpm) via various procedures. Biointerface Res Appl Chem 2019, 9, 4517-1521, https://doi.org/10.33263/BRIAC96.517521.

65. Boussakouran, A.; Sakar, E.H.; El Yamani, M.; Rharrabti, Y. Morphological Traits Associated with Drought Stress Tolerance in Six Moroccan Durum Wheat Varieties Released Between 1984 and 2007. J Crop Sci Biotechnol 2019, 22, 345-353, https://doi.org/10.1007/s12892-019-0138-0.

66. El Yamani, M.; Sakar, E.H.; Boussakouran, A.; Rharrabti, Y. Leaf water status, physiological behavior and biochemical mechanism involved in young olive plants under water deficit. Sci Hortic 2020, 261, https://doi.org/10.1016/j.scienta.2019.108906.

67. El Yamani, M.; Sakar, E.H.; Boussakouran, A.; Rharrabti, Y. Activity of two natural additives in improving the stability of virgin olive oil quality during storage. OCL 2020, 27, 44, https://doi.org/10.1051/ocl/2020039.

68. Sakar, E.H.; El Yamani, M.; Rharrabti, Y. Variability of oil content and its physico-chemical traits from five almond (Prunus dulcis) cultivars grown in northern Morocco. J Mater Environ Sci 2017, 8, 2679-2686.

69. Sakar, E. H.; El Yamani, M.; Rharrabti, Y. Geometrical Traits in Almond Fruit as Affected by Genotypic and Environmental Variations in Northern Morocco. Erwerbs-Obstbau 2019, 61, 103-112, https://doi.org/10.1007/s10341-018-0401-y.

70. Sakar, E.H.; El Yamani, M.; Rharrabti, Y. Fruit Gravimetrical Traits in Almond [Prunus dulcis (Mill.) D.A. Webb]: Combined Effects of Genetic Control and Environmental Drivers. Erwerbs-Obstbau 2020, 62, 37-46, https://doi.org/10.1007/s10341-019-00457-x.

71. Zeroual, A.; Sakar, E.H.; Eloutassi, N.; Mahjoubi, F.; Chaouch,M.; Chaqroune, A. Phytochemical Profiling of Essential Oils Isolated Using Hydrodistillation and Microwave Methods and Characterization of Some Nutrients in Origanum compactum Benth from Central-Northern Morocco. Biointerface Res Appl Chem 2021, 11, 9358-9371, https://doi.org/10.33263/BRIAC112.93589371.

72. El Bouzidi, L.; Abbad, A.; Lahcen, H.; Fattarsi, K.; Leach, D.; Markouk, M.; Legendre, L.; Bekkouche, K. Essential oil composition and antimicrobial activity of wild and cultivated Moroccan Achillea ageratum L.: a rare threatened medicinal species. Chem Biodiv 2011, 9, 598-605, https://doi.org/10.1002/cbdv.201100115.

73. Ait-Sidi-Brahim, M.; Markouk, M.; Larhsini, M. Moroccan Medicinal Plants as Antiinfective and Antioxidant Agents. In: New Look to Phytomedicine: Advancements in Herbal Products as Novel Drug. Khan, M.S.A., Ahmad, I., Chattopadhyay, D. Eds., Academic Press: London, UK, 2019; pp. 91-142, https://doi.org/10.1016/B978-0-12-814619-4.00005-7. 